\title{
Absence of Detectable Xanthine Oxidase in Human Myocardium
}

\author{
Cyril M. Grum, ${ }^{1}$ Kim P. Gallagher, ${ }^{2,3}$ \\ Marvin M. Kirsh ${ }^{2}$ and Marshal Shlafer ${ }^{2,4}$
}

Department of Internal Medicine (Pulmonary and Critical Care Division) ${ }^{1}$, Department of Surgery (Section of Thoracic Surgery $)^{2}$, and Departments of Physiology ${ }^{3}$ and Pharmacology ${ }^{4}$, The University of Michigan Medical School, Ann Arbor, MI, USA

(Received 21 June 1988, accepted in revised form 1 November 1988)

\begin{abstract}
C. M. Grum, K. P. Gallagher, M. M. Kirsh and M. Shlafer. Absence of Detectable Xanthine Oxidase in Human Myocardium. Journal of Molecular and Cellular Cardiology (1989) 21, 263-267. The enzyme xanthine oxidase has been implicated as a generator of toxic oxygen metabolites that contribute to ischemic injury. Because substantial species variability has been demonstrated and because there are minimal human data available, the relevance of xanthine oxidase to human heart damage has been in doubt. We report the absence of xanthine oxidase activity in nine human heart biopsy specimens obtained during cardiac surgery, and in two larger samples obtained during heart transplantation. A sensitive radiochemical assay was used to assess enzyme activity. Our findings imply that oxygen free radicals generated by xanthine oxidase are not relevent in terms of human myocardial injury.
\end{abstract}

KEY WORDs: Ischemia; Oxygen radicals; Myocardial injury.

\section{Introduction}

'Toxic oxygen metabolites have been postulated to participate in acute ischemic and hypoxic myocardial injury (Chambers $e t$ al., 1985; McCord, 1985). Although they may come from many sources, recent studies have emphasized the potential importance of xanthine oxidase which is formed from xanthine dehydrogenase during ischemia or hypoxia (McCord, 1985; Hearse et al., 1986; Parks and Granger, 1986). Indeed, inhibition of xanthine oxidase or limitation of substrate availability for the enzyme does minimize injury in some animal models. However, not all animal models conform to this scheme. In particular, we and others have shown that the ischemic/reperfused rabbit heart does not contain either xanthine oxidase or dehydrogenase (Grum et al., 1986, 1987a ; Downey et al., 1988). Therefore, it appears likely that the myocardial xanthine oxidase system may be more important in some species (e.g. dog, rat) than in others (e.g. rabbit, pig). Species variability raises questions about the applicability of the xanthine oxidase hypothesis to human myocardium. The sparse human data available have yielded conflicting results. Using a variety of enzyme assays and tissue sampling procedures, investigators have reported no xanthine oxidase activity (Ramboer, 1969; Eddy et al., 1987), minute levels of activity (Watts et al., 1965; Muxfeldt and Schaper, 1987), or relatively high levels of activity (Bruder et al., 1984). Using a previously validated sensitive radiochemical assay (Grum $e t$ al., 1986), we report the absence of measurable xanthine oxidase or dehydrogenase activity in human myocardium.

\section{Materials and Methods}

\section{Human heart studies}

A protocol, including written informed consent documents, was submitted to and approved by the Human Use Committee at The University of Michigan (IRB 87-139). We obtained a left ventricular myocardial biopsy from nine patients undergoing cardiac surgery. Each biopsy was obtained before aortic cross-clamping and the induction of

Please address all correspondence to: Cyril M. Grum, The University of Michigan Medical Center, 3916 Taubman Center, Box 0360, Ann Arbor, MI 48109-0360, USA. 
global ischemia. The biopsies were obtained by a small cutting forceps, similar to those used for polypectomy during colonscopy. The biopsies were frozen within $10 \mathrm{~s}$ by immersion in liquid nitrogen, and stored at $-80^{\circ} \mathrm{C}$. Biopsies were processed as described below.

\section{Rat heart studies}

To assess the ability of the enzyme assays to detect activity in small tissue samples, biopsies were obtained from the left ventricular myocardium of six Sprague-Dawley rats that were killed by decapitation. The hearts were immediately biopsied in situ with a forceps identical to that used for human hearts. Biopsies were frozen immediately in liquid nitrogen, stored, and processed as described below.

\section{Tissue preparation}

Frozen biopsies were weighed and immediately placed in $1 \mathrm{ml}$ of an ice cold buffer $(\mathrm{pH}$ 9.0) containing $0.125 \quad \mathrm{M}$ Tris(hydroxymethyl)aminomethane, $10 \mathrm{~mm}$ dithiothreitol (DTT), 1 mm phenylmethylsulfonyl fluoride (PMSF), and 0.1 mM EDTA. The DTT and PMSF were added to prevent in vitro conversion of xanthine dehydrogenase to xanthine oxidase. The tissue was homogenized in the ice cold buffer. The homogenate was spun at $12000 \mathrm{~g}$ for $20 \mathrm{~min}$ at $4^{\circ} \mathrm{C}$. The supernatant was dialyzed at $4^{\circ} \mathrm{C}$ in a $200: 1$ dilution of buffer overnight to remove enzyme inhibitors and endogenous purines. Aliquots were then assayed for enzyme activity.

\section{Enzyme assay}

The radiochemical assay for xanthine oxidase/xanthine dehydrogenase is identical to that which we have described before (Grum et al., 1986). In brief, we optimized enzyme activity according to the method of Mousson et al. (1983). The reaction mixture contained buffer, $\left[8-{ }^{14} \mathrm{C}\right]$ hypoxanthine, and sample, at $37^{\circ} \mathrm{C}$, in a shaking water bath. Six aliquots of each sample were reacted with the radiolabeled hypoxanthine in the presence or absence of $\mathrm{NAD}^{+}$(1 mM final concentration), perchloric acid (283 $\mathrm{mm}$ ), or allopurinol (1 $\mathrm{mm}$ ). This enabled us to assess, individually, the activities of xanthine oxidase alone, xanthine oxidase plus xanthine dehydrogenase, pharmacologic inhibition by allopurin- ol, and baseline counts. Sample counts were adjusted by subtracting the background counts obtained in the perchloric acid-treated controls. The reaction was run for $15 \mathrm{~min}$, since reaction rates become nonlinear thereafter (Watts et al., 1965). All reactions were stopped by adding perchloric acid and immediately chilling the reaction mixtures in ice. The reaction mixture was spotted on electrophoresis paper. Substrate and products were separated with high voltage electrophoresis. The spots were identified under u.v. light, cut. and radioactivity was counted by liquid scintillation spectrometry. Enzyme activity was computed and expressed as milliinternational units/g of wet tissue weight. One mIU corresponds to one nmol of hypoxanthine oxidized/ min.

\section{Results}

The nine human myocardial biopsies weighed $13 \pm 2 \mathrm{mg}$ (mean \pm s.E.M.). The rat heart biopsies weighed $13 \pm 1 \mathrm{mg}$ (not significantly different from human biopsy weights; $P>0.8, t$-test). No xanthine oxidase or xanthine dehydrogenase activity was detected in the human myocardial samples. Under conditions used to assay xanthine oxidase plus xanthine dehydrogenase activity of the human samples, the radioactivity of the electrophoresis spots containing xanthine plus uric acid did not exceed the background radioactivity. The corresponding activity measured under conditions to assess xanthine oxidase activity alone also did not exceed background radioactivity. The addition of allopurinol ( $1 \mathrm{~mm}$ ) to both these assays had no effect. These findings indicate that there is no xanthine oxidase or xanthine dehydrogenase activity present in human myocardial samples based on this assay.

In order to confirm our findings, we obtained larger pieces (150 and $589 \mathrm{mg}$ ) of human myocardium at the time of cardiac transplantation in two patients. This tissue was assayed using the same procedures used for the biopsies. There was no evidence of xanthine dehydrogenase or xanthine oxidase activity.

In contrast, with rat myocardial samples, radioactivity of the xanthine and uric acid spots obtained under conditions measuring 
TABLE 1

\begin{tabular}{lccc}
\hline & \multicolumn{3}{c}{ Enzyme activity $(\mathrm{mIU} / \mathrm{g}$ wet wt)* } \\
\cline { 2 - 4 } & $\mathrm{XO} / \mathrm{XD}$ & $\mathrm{XO}$ & $\mathrm{XD}$ \\
\hline Rat heart biopsies $(n=6)$ & $98.1 \pm 24.3$ & $54.9 \pm 17.7$ & $43.2 \pm 14.5$ \\
$\begin{array}{l}\text { Human heart biopsies }(n=9) \\
\text { Human heart transplant }(n=2)\end{array}$ & 0 & 0 & 0 \\
$\quad$ samples & & 0 & 0 \\
\hline
\end{tabular}

* $\mathrm{XO} / \mathrm{XD}$, combined xanthine oxidase and dehydrogenase activity; $\mathrm{XO}$, xanthine oxidase activity; XD, xanthine dehydrogenase aclivily.

both xanthine oxidase and dehydrogenase exceeded background by $1281 \pm 308 \mathrm{ct} / \mathrm{min}$ $(P<0.001 ; t$-test $)$. The corresponding counts for xanthine oxidase alone exceeded background by $682 \pm 132 \mathrm{ct} / \mathrm{min} \quad(P<0.001$; $l$-test). The counts per minute for rat myocardial samples run in the presence of allopurinol were not different from background counts $(P>0.4 ; t$-test $)$. This indicated that allopurinol completely inhibited xanthine oxidase activity. The computed enzyme activities are shown in Table 1. Total enzyme activity (oxidase plus dehydrogenase) was only slightly higher than that which we have previously reported for whole rat hearts (62 $\mathrm{mIU} / \mathrm{g}$ wet wt; Grum et al., 1986), or the value reported by Eddy et al. (1987; 77 $\mathrm{mIU} / \mathrm{g}$ wet $\mathrm{wt}$ ). However, our microsampling technique resulted in a greater percentage of the enzyme in the oxidase form. We believe manipulation and processing of the small biopsies caused the increased conversion of xanthine oxidase to dehydrogenase.

\section{Discussion}

Our main finding is that we did not detect any xanthine oxidase or dehydrogenase activity in human myocardial biopsies. This supports the data of Eddy et al. (1987), that in terms of xanthine oxidase, human myocardium appears more similar to rabbit myocardium than to rat or dog myocardium. Our present study using a sensitive radiochemical assay corroborates the postulate of Downey $e t$ al. (1988), that xanthine oxidase-mediated degradation of hypoxanthine is an important potential source of free radicals in the ischemic myocardium of some, but not all, species.
Previous efforts to measure xanthine oxidase in human myocardium have suffered from methodological difficulties and, not surprisingly from conflicting results. Watts $e t$ al. (1965) found minute levels (i.e. less than 1 $\mathrm{mIU} / \mathrm{g}$ protein) in two cadaver hearts. Ramboer (1969) could not detect any activity in a cadaveric sample. Cadaver values however may be influenced by preterminal release of xanthine oxidase into plasma from necrotic liver. More recently, Muxfeldt and Schaper (1987), using a standard spectrophotometric assay, have reported barely detectable $(0.013 \mathrm{nmol} / \mathrm{min} / \mathrm{g}$ wet $\mathrm{wt})$ xanthine oxidase activity in tissue from one human heart obtained during surgery. This level of activity is lower than that found in the hearts of other species with the exception of the rabbit heart. On the other hand, the preliminary finding by deJong et al. (1987) that human heart can produce significant amounts of uric acid had led them to conclude that xanthine oxidase activity is present. Jarasch and coworkers have noted immunofluorescent staining of human myocardial capillaries using xanthine oxidase antibodies (Bruder $e t$ al., 1984 ; Jarasch et al., 1986). However, they used antibodies to milk xanthine oxidase, and human myocardium may possess an enzyme form that is neither xanthine oxidase nor dehydrogenase but can cross-react with the antibody (Downey et al., 1988). Jarasch and colleagues therefore did not report xanthine oxidase activity, but the presence of material that reacts to anti-bovine xanthine oxidase antibodies. The most convincing evidence for the lack of xanthine oxidase in human heart used a modified spectrophotometric assay (Eddy et al., 1987), applied to heart samples from four patients. They used matched allopurinol controls to compensate for the 
unknown peak which coabsorbs with uric acid. We obtained the same outcome using a very sensitive radiochemical assay that has been thoroughly validated in the past, both by others (Mousson et al., 1983; Sinclair and Fox, 1975) and in our previous experiments (Grum et al., 1986). In addition, our methods for processing and analyzing the human myocardial biopsies were identical to those used for rat myocardial biopsies, a species characterized by relatively high levels of xanthine oxidase and dehydrogenase.

Thus we concur that xanthine oxidase and xanthine dehydrogenase do not exist (or exist at very low concentrations) in the human myocardium. This enzyme system therefore is not likely to be important in ischemic/ reperfusion injury of the human heart. In choosing an experimental model of ischemiareperfusion injury that realistically simulates human myocardial injury, we propose that a model devoid of xanthine oxidase may be the most appropriate. In rat and dog ischemicreperfusion injury, xanthine oxidase generation of oxygen radicals appears to play a major role. Data at this point suggests that the rabbit model, and possibly the pig model, may be the most rational option to examine human ischemic/reperfusion myocardial injury (Grum et al., 1986, 1987a; Muxfeldt and Schaper, 1987; Downey et al., 1988).
Studies of the xanthine oxidase and dehydrogenase system may nonetheless be relevant to human disease. Xanthine oxidase and dehydrogenase are present in human liver and small intestine in high concentrations (Mousson et al., 1983). In some forms of acute diffuse lung injury, and in acute liver injury, xanthine oxidase is present in human plasma and therefore could be transported to the myocardium (Shamma'a et al., 1965; Grum et al., 1987b). Toxic oxygen metabolites could then be generated when the circulating xanthine oxidase reacts with the increased purines formed during ischemic myocardial episodes. In addition, human neutrophils may contain xanthine oxidase (Jones et al., 1985). Finally, studies of xanthine oxidase inhibitors, e.g. allopurinol) have shown beneficial effect on injury by a pathway not related to enzyme inhibition (Myers et al., 1985, 1986; Downey et al., 1988).

\section{Acknowledgements}

We thank G. Michael Deeb, M.D. and Steve J. Bolling, M.D. for providing heart tissue during heart transplantation. Supported by grants from the National Institutes of Health (HL29499, HL01930-01, GCRC RR4225S2); the American Lung Association; and the American Heart Association of Michigan.

\section{References}

Bruder G, Jarasch E-D, Heid HW (1984) High concentrations of antibodies to xanthine oxidase in human and animal sera. Molecular characterization. J Clin Invest 74 : 783-794.

Chambers DE, Parks DA, Patterson G, Roy R, McCord JM, Yoshida S, Parmley, LF, Downey JM : 1985 ) Xanthine oxidase as a source of free radical damage in myocardial ischemia. J Mol Cell Cardiol $17: 145-152$.

DeJong JW, Czarnecki W, Huizer T, Serruys PW, Herbagzynska-Cedro K (1987) Urate production by human heart. [abstr.] Eur Heart J 8 [Suppl 2]: 27.

Downey JM, Hearse DJ, Yellon DM (1988). The role of xanthine oxidase during myocardial ischemia in several species including man. J Mol Cell Cardiol 20 [Suppl II] : 55-63.

Eddy LJ, Stewart JR, Jones HP, Engerson TD, McCord JM, Downey JM (1987) Free radical-producing enzyme, xanthine oxidase, is undetectable in human hearts. Am J Physiol 253 (Heart Circ Physiol 22) : 11709-H711.

Grum CM, Ketai LH, Myers CL, Shlafer M (1987a) Purine efflux after cardiac ischemia : relevance to allopurinol cardioprotection. Am J Physial 252: H368-H373.

Grum CM, Ragsdale RA, Ketai LH, Shlafer M (1986) Absence of xanthine oxidase or xanthine dehydrogenase in the rabbit myocardium. Biochem Biophys Res Commun 141 : $1104-1108$.

Grum CM, Ragsdale RA, Ketai LH, Simon RH (1987b) Plasma xanthine oxidase activity in patients with ARDS. J Crit Care 2: 22-26.

Hearse DJ, Manning AS, Downey JM, Yellon DM (1986) Xanthine oxidase: a critical mediator of myocardial injury during ischemia and reperfusion? Acta Physiol Scand 548 [Suppl]: 65-78.

Jarasch ED, Bruder G, HeId HW (1986) Significance of xanthine oxidase in capillary endothelial cells. Acta Physiol Scand 548 [Suppl]: 3946 .

Jones HP, Grisham MB, Bose SK, Shannon VA, Schott A, McCord JM (1985) Effect of allopurinol on neutrophil superoxide production, chemotaxis, or degranulation. Biochem Pharmacol 34: 3673-3676.

McCorn JM (1985) Oxygen-derived free radicals in postischemic tissue injury. N Engl J Med 312: 159163. 
Mousson B, Desjacques P, Baltassat P (1983) Measurement of xanthine oxidase activity in some human tissue: : an optimized method. Enzyme 29 : 32-43.

Muxfeld M, Schaper W. (1987) The activity of xanthine oxidase in heart of pigs, guinea pigs, rabbits, rats, and humans. Basic Res Cardiol 82: 486-49?.

Myers CL, Weiss SJ, Kirsh MM, Shepard BM, Shlafer M (1986) Effects of supplementing hypothermic crystalloid cardioplegic solution with catalase, superoxide dismutase, allopurinol, or deferoxamine nn functional recovery of globally-ischemic and reperfused isolated hearts. J Thorac Cardiovasc Surg 91 : $281 \cdots 289$.

Myers CL, Weiss SJ, Krrsh MM, Shlafer M. (1985) Involvement of hydrogen peroxide and hydroxyl radical in the 'oxygen paradox': reduction of creatinine kinase release by catalase, allopurinol or deferoxamine, but not by superoxide dismutase. J Mol Cell Cardiol 17:675 684.

Parks DA, Granger DN (1986). Xanthine oxidase: biochemistry, distribution and physiology. Acta Physiol Scand 548 [Suppl] : 87-99.

RAMBoER CRH (1969) A sensitive and nonradioactive assay for serum and tissue xanthine oxidase. J Lab Clin .Med 74 : $828-835$

Shamma a MH, Nasrallah S, Chaglassian T, Kachadurian AK, Al-Khalddi UAS (1965) Serum xamthine oxiditse: a sensitive test of acute liver injury. Gastroenterology 48 : 226-230.

SINCLAIR DS, Fox IH (1975) The pharmacology of hypouricemic effect of benzbromarone. J Rheumatol 2: $437-445$.

Watts RWE, Watts JEM, SeEgmiller JE (1965) Xanthine oxidase activity in human tissues and its inhibition by allopurinol (4-hydroxypyrazolo [3,4-d] pyrimidine). J Lab Clin Med 66 : 688-697. 